\title{
Impact of Advertising on Brand Awareness and Consumer Preference (With Special Reference to Men`S Wear)
}

\author{
Ms. Roshni P Sawant \\ Dept of Business Management Padashree Dr D Y Patil University, Mumbai, India
}

\begin{abstract}
The word is speeding into information age. Style is taking a sent next to substance and the bar gauge of commerce is shifting to images and perceptions from nuts and bolts. As a result everyone is jumping on the brand wagon. Brands are bigger than every, but as a result it is also true that more than ever is expected of them. In today's world a brand occupies a space on the consumer landscape much like tat of a person. Advertising also provides the necessary support after the consumer has made the purchase. If the consumers experience dissonances or discomforts owing to their purchase decision, then advertisement reduces this feeling of discomforts y providing information on the products attributes. It is even more necessary to neutralize the impact of the advertisements of rival brands. The subsequent paper endeavors to gauge the role of advertising in promoting brand predominantly in the perspective of men's wear.
\end{abstract}

Keywords: Branding, Advertising, consumer preference, Brand equity, Brand Awareness

\section{Introduction}

Brand! Brand!! Brand!!! That's the message for the late 90's and beyond (Tom peters in the circle of innovation 1997)(1) Brands are everywhere today, in familiar places and also in distant lands where you might not expect. Stickers on soccer goals,'6'or'4' ply cards in a cricket match kids chirpily proclaiming 'coco cola enjoy' or 'Pepsi dil maange more'. Clothing, household items, buildings buses, taxies, milk packets etc all contain advertisements which symbolizes brands of the sponsors. On the internet they pop up out of nowhere trying to sell something. It, therefore, wont be wrong to say "the world is under brand bombardment". Why? It is because a physical product is only a part of the product image. It cannot stand alone before the potential buyer. Products may have peripheral or associated attribute to facilitate its identification and acceptance by the buyers. It is the brands, the ideas, words graphics, designs and sounds that symbolizes products, services and companies behind them and they are hot and happening in business today. Branding is a process of stamping a product or a group of products or something else which the marketer offers, with some identifying name and mark or combination of both. It creates individuality in the offering facilitating it to be easily distinguished and recognized in the market from rival offerings. The word brand is a comprehensive term. It can encompass a name, a word, a phrase, a design, a symbol or a combination of these elements in order to distinguish one product from another. A brand, by definition, is a short hand description of a package of value, on which consumes can rely to be consistently the same or better over a period of time. A brand stars as a product and a name, but much can be built on the name. a brand identifies the product for a buyer and gives seller a chance to earn goodwill and repeated patronage. The owner of a registered brand personally stands behind the branded product and offers personal guarantee for maintaining the quality and standards of the product. A genuine brand has three basic characteristics The internalized sum of impressions as received, by the consumers, leading to a distinctive position, in their mind space, based on emotional and functional benefits.(2) Evolutions of Brands- Brands start off as products made out of certain ingredients over a period of time, brands are built through marketing activities and communication. They keep on acquiring attributes, core values and extended values.

Compondium of Brand Managomont
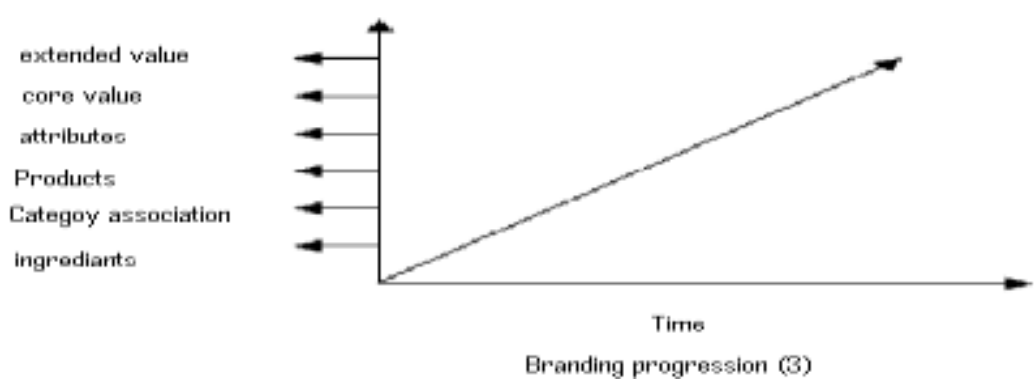


\section{Consumer preferences towards brand indicate the following:-}

1. Brand Unawareness- A buyer has no knowledge of the existence of the brand.

2. Brand Awareness- A buyer is aware of the existence of the brand but the knowledge about it is limited and obviously has no particular emotional attachment to it as a result he may or may not think of purchasing the brand.

3. Brand Acceptance- A buyer can buy the brand as he has no negative feeling about the brand but he has open mind to try another brand.

4. Brand Preference- The buyer favours a particular Brand but he can think for other brand which is next in his preference schedule.

5. Brand Loyalty-The attachment towards a particular Brand is very strong and if the brand is unavailable, only then, he can think of buying another brand.

6. Brand Insistence- A buyer insists on purchasing and one brand only and will not at all accept a substitute.

7. Brand Equity- In the 80s much of the growth of the giant consumer product corporation was achieved by a strategy of acquiring valuable brand names from other companies, often the price paid for such transaction is huge. This is quite obvious that brand names that are well known and wee liked by the consumer have greater equity hence are worth more, David Aaker feels (4). Brands have equity because they have high awareness, many loyal consumers, a high reputation for perceived quality.

\section{A schematic version of David Aaker`s Brand Equity appears in the figure below- Brand Equity: An Overview [5]}

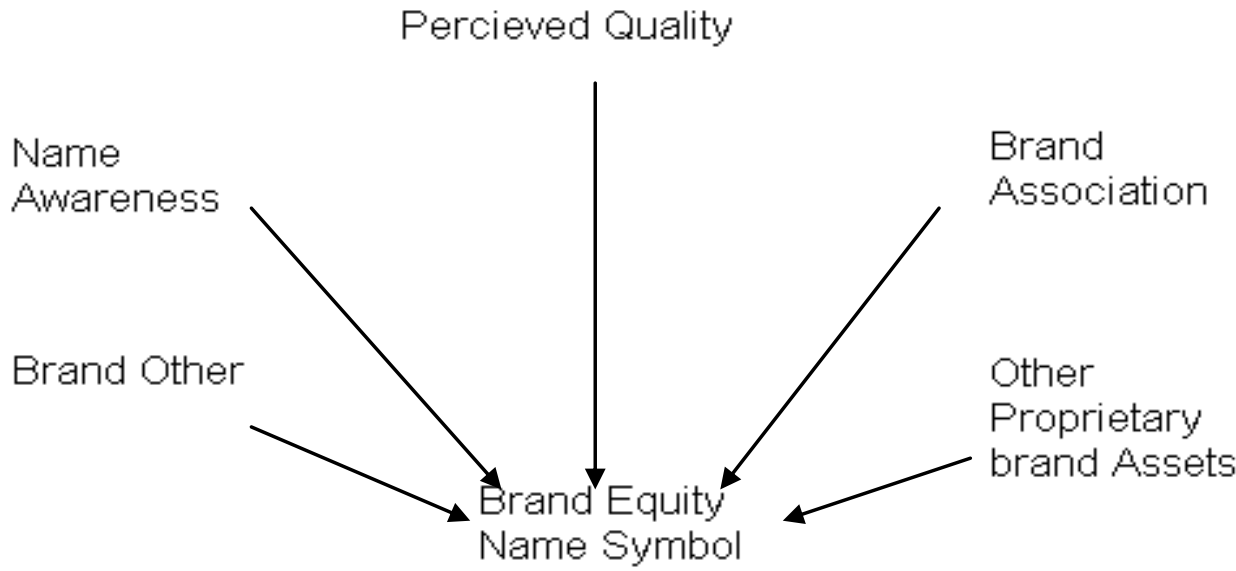

Provides value to customers by enhancing customers

1. Interpretation/

Processing of

Information

2. Confidence in

Purchase

3. Use Satisfaction
Provides Value to Firm by

Enhancing-

1. Efficiency \& Effectiveness Of

Marketing Programme

2. Brand Loyalty

3. Prices/ Margins

4. Brand Extension

5. Trade Leverage

6. Competitive Advantage

The world is speeding into the information age. Style is taking a seat next to substance and the language of the commerce is shifting to images and perceptions from nuts and bolts. As a result everyone is jumping on the brand wagon. Brands are bigger than ever, but as a result it is also true that more than ever is expected of them. One can say when the choices have become vast the only thing that will matter are brand names. In today's world a brand occupies a space on the consumer landscape much like that of a person. It may be a reassuring friend, a pompous hypocrite, a seductive fastener, an inspiring leader or an irritating nag. It may excite confuse, provide comfort, challenge, annoy, often just another face in the crowd that no one notices much at all. "People don't necessarily have relationships with corporations but they do have relationships with brands, that might symbolizes corporation or what the corporation produces" observes Rita Clifton, [6]. She goods on , when you get into group discussions, consumers talk about brands like people. They can describe their personalities. They can say if this brand came to life it would be this colour, this age. People talk about brands as friends". 


\section{Advertising and Brand Awareness-}

Now it is very well known that since Brands are coming in by dozens, all one needs is the confidence to deliver, to just make it happen- by none other than advertising which forms a vast superstructure with an autonomous existence and an immense influence.

Today there is general agreement that advertising objectives can be set around four broad themes:-

- The behavioral constructs generating trial purchases and store visit.

- Change in attitude and its measurement

- Positioning of the product and brand building.

- Creating awareness of new products and brands.

Advertising is one of the most important cultural sign systems that reflect and mould our lives. It is an inevitable part of anyone's life. Even if one does not read the newspaper or watches television it is impossible to escape the advertising images that pervade our surroundings, via hoardings, wall paintings, pop material or even the radio, cutting across all media but limited to none.

It is true that Brand Awareness is one of the prime objective of Advertising in the modern world of 'me too Brands'. It is this ad mad world full of dream merchants which as created the concept of 'jo dikhta hai wohi bikta hai'. Advertising is the communication link between the seller and the buyer. It does not simply provide information about the products and services but is an active attempt to influencing people to action by an overt appeal to reason or emotion. In other words, advertising does not end with the flow of information from the seller to the buyer; it goes further to influence and persuades people to action or belief. Advertising, being an integral part of promotion mix, is a part of the total marketing mix and it influences the sale of the products as do the other variables of the mix. Together with the product or brand, price, channel or distribution outlet and personal selling it attempts to achieve the marketing objectives.

\section{Advertising and Consumer Behaviour:-}

Relationship consumer behaviour is influenced by various factors, ranging from personal motivation, needs attitude and values, personality characteristics, socio-economic and cultural background, age, sex, professional status to social influence of various kinds exerted by family, friends colleagues and society as a whole. Each person has his / her own standards of judgments and distinct behaviour in every aspects of his/ her role as a consumer. But, at the same time, underlying the individual differences there are similarities which make it possible to explain behaviour of specific types or groups of people. A careful study of consumer behaviour provides the advertiser with deeper insight of his target segments, which in turn proves to be very valuable in strategic advertising decisions, especially in defining the target markets and creating the advertising appeal and message.

\section{How dose Advertising affects consumers-}

Advertising, along with a number of other factors viz price, distribution, sales force, packaging, product features, competitive actions and changing buyer needs and tasters influence sales isolating the effects of advertising is extremely difficult. Advertising might attract buyers who will be loyal customers for many years to come or might start the development of positive attitudes or brand equity that will culminate in purchase much later. Advertising influences consumer and his decision making in a number of ways. It not only educated him about his problems or needs, provides required information and assists him in comparing the various alternatives and arriving at final decision. As it is a cyclical process, it also has impact over the post purchase behavior of the consumer.Often, the consumers are either not aware of their needs or are confused about their problems. To them, advertising provides clues; therefore advertising provides the consumer motives to purchase the advertised product. As in the present scenario the strategy is to keep on changing or improving the product. As in the present scenario the strategy is to keep on changing or improving the product or its features, it becomes imperative top inform the consumers about the minor innovations and the way it can solve their problems - the problems which the consumers feel and is at the surface or the problems which had not captured the attention of the consumers. Advertising also provides the necessary support after the consumer has made the purchase. If the consumers experience dissonance or discomforts Moving to their purchase decision, then advertisement reduce this feeling of discomfort by providing information on the products attributes. It is even more necessary to neutralize the impact of the advertisements of rival brands.Keeping the above facts in view an attempt has been made to find out whether advertising has an impact on brand awareness and preference on men's garment in the study area of Navi Mumbai, has also experienced the sift in men's shopping pattern and methodology used as the city wittiness significant economic, demographic, social cultural development. People of this city are customizing them selves to the fashion revolution and men are a major contributing factor and greatly affected by the same as well. New avenues are reshaping and redirecting the general marketing/shopping culture prevalent .Navi Mumbai is the world's largest planned city - Vital Statistics of Navi Mumbai 
Population of 703,947( census 2001) Males 56\% Females 44\%. Navi Mumbai has an average literacy rate of $74 \%$, higher than the national average of $59.5 \%$ : male literacy is $79 \%$, and female literacy is $67 \%$. In Navi Mumbai, $14 \%$ of the population is under 6 years of age, with $28 \%$ in the age group of up to 15 years, $55 \%$ in the age group of $15-44$ year bracket and $13 \%$ aged $45-59$. Average family size is 4.05 persons, compared to Mumbai's average of $4.85 .67 \%$ of families living in Navi Mumbai own their homes and of the working population, $63.5 \%$ are employed within the city

\section{Salient Features}

Most of the software companies in Maharashtra have their offices in Navi Mumbai. The International Infotech Park at Vashi and Belapur railway station complex houses many international IT companies. Proposed International Airport will be constructed in Navi Mumbai. There are adequate utility services, banks, restaurants, malls, multiplexes and other shops in Navi Mumbai. Vashi boasts several shopping malls such as Center One, Palm Beach Galleria, Citi Center, Raghuleela Mall and Inorbit Mall. Palm Beach Road, Nerul, and Kharghar are also witnessing the construction of malls and multiplexes. Throughout Navi Mumbai supermarkets and malls like Apnaa Bazaar, More, Spencer's, Reliance Fresh, Spinach and Fairprice cater to the shopping needs of the residents. DMart has launched five hypermalls in Navi Mumbai.

- To study, the impact of advertising on consumer's brand awareness.

- To study, relationship between brand awareness and its impact on consumers preferences.

- To study, brand awareness in different demographic groups and their final preference and choice.

- To study, the impact of other factors in brand preference of readymade garments.

- To study, the state of switching and the impact of advertising on brand switching of advertising.

\section{Research Methodology:}

The study of focused all men's wear, there are 30 big outlets offering wide assortment of brands along with it there are about 50 big shops selling suiting and shirting. There are Exclusive showrooms of Bombay Dyeing, DCM, Cotton County, Koutons, Peter England, TNG and Cantabil along with an innumerable other small outlets selling readymade as well as suiting and shirting. Along with the advertising efforts of the brands the local distributors contribute in the forms of having their hoardings at prime locations along with banners and posters at prominent crossing of the main markets, neighborhood markets and residential localities. Advertising in local news papers and magazines is also resorted to. The local channels also have advertising film clips of the reputed shops.

\section{Discussions}

As per table 1rank Co-efficient of Correlation between Awareness and Awareness owing to Advertising in readymade outfits - +0.95 Rank Co-efficient of Correlation between Awareness owing to Advertising and Consumer preference in readymade outfits - +0.86 It, therefore signifies very high degree of positive correlation in both the cases. Coefficients of determination are $0.86 \& 0.74$ respectively which signifies that $86 \%$ of awareness is owing to advertising and $74 \%$ of consumer preference of readymade is owing to awareness created by advertising. Alternative test for determining significance of $r$ is to apply ' $t$ ' test to the computed ' $r$ ' value with a null hypotheses that there is no relationship between awareness and awareness owing to advertising \& consumer preference is not affected by awareness owing to advertising in readymade wears. The value of ' $t$ ' was $23 \& 16.54$ respectively, we assume the $95 \%$ confidence level is selected. Referring to a students ' $t$ ' table for 56 degree of reedom since the number of brands in the study were 58 shows the critical value of ' $t$ ' 2 at $95 \%$ confidence level. The computed value is greater than the critical value hence we can conclude that the null hypothesis are rejected and conclude that there are significant relationships between awareness and awareness owing to advertising $\&$ consumer preference owing to advertising awareness.

Table 1 showing Brand Awareness, Awareness owing to Advertising and Consumer preference owing to Advertising Awareness, in readymade outfits.

\begin{tabular}{|l|l|l|l|l|l|l|}
\hline Brand & Awareness & & $\begin{array}{l}\text { Advertising } \\
\text { Awareness }\end{array}$ & & $\begin{array}{l}\text { Consumer } \\
\text { Preference }\end{array}$ & \\
\hline & Nos. & Rank & Nos. & Rank & Nos. & Rank \\
\hline & & & & & & \\
\hline Allen Solly & 189 & 4 & 182 & 4 & 110 & 4 \\
\hline Arrow & 109 & 26 & 104 & 24 & 30 & 22 \\
\hline Benzer & 54 & 44 & 50 & 42 & 9 & 55.5 \\
\hline Berkeley & 9 & 57 & 8 & 57 & 1 & 43 \\
\hline Bombay Dyeing & 178 & 9 & 152 & 10 & 20 & 31 \\
\hline
\end{tabular}




\begin{tabular}{|c|c|c|c|c|c|c|}
\hline Blackberrys & 62 & 42 & 58 & 40 & 5 & 47.5 \\
\hline Carante & 124 & 22 & 120 & 19 & 28 & 24 \\
\hline Cantabil & 176 & 10 & 148 & 12 & 75 & 8 \\
\hline Casabalanka & 152 & 14 & 140 & 15 & 41 & 16 \\
\hline Century & 140 & 16 & 85 & 30 & 10 & 40.5 \\
\hline Charagdin & 182 & 6 & 167 & 7 & 25 & 27 \\
\hline Colour Plus & 84 & 33 & 66 & 36 & 11 & 38 \\
\hline Cotton country & 160 & 11 & 142 & 14 & 72 & 9 \\
\hline Crocodile & 101 & 31 & 86 & 29 & 12 & 35.5 \\
\hline Dash & 52 & 45 & 15 & 52 & 11 & 38 \\
\hline Diwan Sahab & 34 & 49 & 29 & 46 & 1 & 55.5 \\
\hline Euro & 20 & 52 & 16 & 51 & 2 & 52 \\
\hline Excalibur & 105 & 30 & 102 & 25 & 40 & 18 \\
\hline Frontline & 81 & 36 & 80 & 33 & 9 & 43 \\
\hline Indigo Nation & 70 & 38 & 65 & 37 & 15 & 33.5 \\
\hline John Player & 61 & 43 & 59 & 39 & 21 & 30 \\
\hline Killer & 135 & 17 & 129 & 17 & 30 & 22 \\
\hline Koutons & 195 & 3 & 192 & 2 & 123 & 1 \\
\hline Lawman & 127 & 21 & 125 & 18 & 36 & 19 \\
\hline Lee & 106 & 29 & 90 & 28 & 32 & 20 \\
\hline Lee Cooper & 82 & 35 & 79 & 34 & 11 & 38 \\
\hline Logo & 41 & 47 & 40 & 43 & 2 & 52 \\
\hline Louis Phillipe & 157 & 13 & 150 & 11 & 99 & 5 \\
\hline Mirror Image & 40 & 48 & 26 & 47 & 22 & 29 \\
\hline Monopoly & 64 & 41 & 25 & 48 & 10 & 40.5 \\
\hline Monte Carlo & 205 & 1 & 185 & 3 & 116 & 2 \\
\hline Moustache & 131 & 19 & 115 & 20 & 30 & 22 \\
\hline Newport & 179 & 8 & 165 & 8 & 70 & 11 \\
\hline Numero Uno & 147 & 15 & 147 & 13 & 95 & 6 \\
\hline Oxzemberg & 107 & 28 & 101 & 26 & 12 & 35.5 \\
\hline Pantaloon & 159 & 12 & 156 & 9 & 61 & 12 \\
\hline Park Avenue & 183 & 5 & 180 & 5 & 51 & 13 \\
\hline Parx & 69 & 39 & 60 & 38 & 9 & 43 \\
\hline Pepe & 22 & 51 & 13 & 53 & 3 & 49 \\
\hline Peter England & 181 & 7 & 175 & 6 & 115 & 3 \\
\hline Pre & 19 & 53 & 18 & 50 & 1 & 55.5 \\
\hline Proline & 110 & 25 & 100 & 27 & 27 & 25 \\
\hline Provogue & 117 & 23 & 109 & 21 & 23 & 27 \\
\hline Rays & 67 & 40 & 55 & 41 & 15 & 33.5 \\
\hline Rockey S & 15 & 55 & 10 & 56 & 1 & 55.5 \\
\hline Rugger & 45 & 46 & 39 & 44 & 7 & 45 \\
\hline Sarar & 7 & 58 & 7 & 58 & 1 & 55.5 \\
\hline Culler & 11 & 56 & 11 & 55 & 2 & 52 \\
\hline Stanza & 115 & 24 & 108 & 22 & 16 & 32 \\
\hline Tibre & 87 & 32 & 84 & 31 & 6 & 46 \\
\hline T N G & 108 & 27 & 105 & 23 & 38 & 18 \\
\hline Van Heusen & 201 & 2 & 199 & 1 & 71 & 10 \\
\hline $\mathrm{W}$ & 16 & 54 & 12 & 54 & 5 & 47.5 \\
\hline Weekender & 33 & 50 & 32 & 45 & 25 & 26 \\
\hline Wills Life Style & 83 & 34 & 81 & 32 & 42 & 15 \\
\hline Wrangler & 79 & 37 & 67 & 35 & 50 & 14.5 \\
\hline Zodiac & 129 & 20 & 128 & 17 & 81 & 7 \\
\hline Others & 134 & 18 & 21 & 49 & 3 & 49.5 \\
\hline
\end{tabular}

As per Table 2 in Annexure 4, Rank coefficient of correlation between awareness and awareness owing to advertising in suiting and shirting -+0.982 rank coefficient of correlation between awareness owing to advertising and consumer preference in suiting and shirting -+ 0.95 . It therefore, signifies very high 
degree of positive correlation in both the cases. Coefficient of determination are 0.95 and 0.90 respectively which signifies that $95 \%$ of awareness is owing to advertising and $90 \%$ of consumer preference of suiting and shirting is owing to awareness created by advertising. Alternative test for determining significance of $r$ is to apply ' $t$ ' test to the computed ' $r$ ' value with a null hypotheses that there is no relatinship between awareness and awareness owing to advertising and consumer preference is not affected by awareness owing to advertising in readymade wears. The value of 't' was 282 and 15.78 repectively. we assume the $95 \%$ confidence level is selected. Referring to student ' $t$ ' table for 33 degree of freedom since the number of brands in the study were 35 shows the critical value of ' $t$ '-2.03 at $95 \%$ confidence level. The computed value is greater than the critical value hence we can conclude that the null hypothesis are rejected and conclude that there $\mathrm{r}$ significant relationship between awareness and awareness owing to advertising and consumer preference owing to advertising awareness.

Table 2 Table showing Brand Awareness, Awareness owing to Advertising and Consumer preference owing to Advertising Awareness, in Suiting and Shirting.

\begin{tabular}{|c|c|c|c|c|c|c|}
\hline Brand & Awareness & & $\begin{array}{l}\text { Ad. } \\
\text { Awareness }\end{array}$ & & $\begin{array}{l}\text { Consumer } \\
\text { Preference }\end{array}$ & \\
\hline & Nos & Rank & Nos. & Rank & Nos. & Rank \\
\hline Arvind & 183 & 15 & 167 & 13 & 36 & 11 \\
\hline Ashima & 123 & 22 & 81 & 22 & 8 & 23 \\
\hline Binny's & 165 & 16 & 142 & 18 & 29 & 14.5 \\
\hline Bombay Rayon & 36 & 30 & 21 & 28 & 4 & 28 \\
\hline Cemtury & 142 & 20 & 62 & 24 & 10 & 22 \\
\hline Digjam & 213 & 4 & 209 & 3.5 & 82 & 5 \\
\hline Dinesh & 219 & 1 & 209 & 3.5 & 42 & 10 \\
\hline Donear & 207 & 6 & 204 & 6 & 29 & 14.5 \\
\hline D C M & 190 & 12 & 162 & 14 & 18 & 19 \\
\hline Ferrino Mezzino & 80 & 26 & 72 & 23 & 16 & 20 \\
\hline Grasim & 209 & 5 & 208 & 5 & 87 & 2 \\
\hline Graviera & 201 & 9 & 200 & 8 & 84 & 3 \\
\hline Gwalior & 204 & 8 & 186 & 10 & 63 & 7 \\
\hline Indian Terrian & 56 & 28 & 46 & 25 & 5 & 25.5 \\
\hline $\mathrm{JCT}$ & 83 & 24 & 40 & 26 & 5 & 25.5 \\
\hline J. Hampsted & 161 & 17 & 143 & 17 & 24 & 16 \\
\hline Linen Club & 28 & 32 & 18 & 30.5 & 2 & 33 \\
\hline Madura Coats & 133 & 21 & 105 & 20 & 11 & 21 \\
\hline Mahajan & 101 & 23 & 84 & 21 & 7 & 24 \\
\hline Maxwell & 40 & 29 & 20 & 29 & 2 & 33 \\
\hline Mayur & 195 & 11 & 193 & 9 & 31 & 12.5 \\
\hline Mikado & 152 & 19 & 128 & 19 & 19 & 17.5 \\
\hline Mistair & 153 & 18 & 150 & 16 & 19 & 17.5 \\
\hline Morarjee & 82 & 25 & 34 & 27 & 4 & 28 \\
\hline $\mathrm{OC} \mathrm{M}$ & 200 & 10 & 170 & 12 & 31 & 12.5 \\
\hline Paparazze & 23 & 33 & 16 & 32 & 3 & 30 \\
\hline Raymonds & 218 & 2 & 215 & 1 & 89 & 1 \\
\hline Reid \& Taylor & 189 & 13 & 184 & 11 & 60 & 8 \\
\hline Shamken & 21 & 34 & 4 & 35 & 2 & 33 \\
\hline Siyaram's & 215 & 3 & 213 & 2 & 80 & 6 \\
\hline S. Kumars & 185 & 14 & 158 & 15 & 47 & 9 \\
\hline Stanfab & 72 & 27 & 18 & 30.5 & 4 & 28 \\
\hline Uniworth & 30 & 31 & 6 & 34 & 2 & 33 \\
\hline Vimal & 205 & 7 & 202 & 7 & 83 & 4 \\
\hline Welspun & 19 & 35 & 7 & 33 & 2 & 33 \\
\hline
\end{tabular}




\section{Conclusion}

- Readymade garments are becoming popular even in navi Mumbai predominantly with youths.

- All the facts included in the study to elicit the reason for purchase e of readymade garments were found to be consequential but satellite channels and growing popularly of readymade garments were found to be relatively most decisive.

- Better fitting garments ,awareness of brand coupled with availability of leading names, latest designs and varieties were found to be primarily responsible for youths opting for readymade garments.

- Provocation by advertising was the foremost factor for buying of garments, followed by the demonstration effect and requirement of dress.

- The youth were found to be more eager to wear new garments as soon as they have bought them.

- It was found to be a general attitude that man preferred to be always well dressed up meaning there with that the concept of looking good and well groomed is becoming remarkably popular with male.

- Ignoring criticism regarding choice of brand and garments was prominent in males; it was even if the criticism was made by intimates.

- It was a common feature with the good number of males that they were conscious about whether people close to them were observant or paying attention to their new dress.

- It was found to be general practice that garment/dresses no longer fashionable were discarded by males.

- Both predeciding the brand to be brought or deciding at the point of purchase were found in practice, but the later was more resorted to.

- It was a general feeling that rigorous advertising was primarily responsible for popularizing ready made garments.

- Personal choice was the foremost reason in selecting a brand followed by rigorous advertising and approbations of close contact and acquaintances demonstration effect figured last.

- It was in general attitude even man preferred to see a good number of arrays and variant before finally selecting the garment.

- Although advertising was found to be primarily responsible for popularizing brands but it was found meaningful in creating brand awareness and elicit interest only. For information pertaining to the brand and depiction of the varieties people resort to p.o.p visits. It is quite obvious two most effective media visual and prints have their limitations. Visual media being very expensive and owing to the fact that frequent insertions are required even to popularize a brand can portray only limited assortments of the brand. Similarly print media too can accommodate very little of the wide range of the brands. P.O.P display coupled with the efforts of the sales personal can be more meaningful on the portrayal of all what the brand has for its customers.

- Price no longer dominates when it comes to having the choicest garment but still only a few are willing to spend an exorbitant sum of money for the brands which appear to be eye-catching or opposite, so it will be wrong to say that prices are ignored at all.

- Print media was found to be the mot effective media as the men can see them repeatedly resultant in a permanent impression of the brand and the option of varieties, followed by mural media which gives the information that the brand is available in the city. Film magazines, Sunday supplements of English newspapers, lifestyle magazines were found to be pertinent with the males, in their choice making.

- Males were found to be equally divided when asked that whether they preferred to be assisted by the stores sale personnel or to be left alone in their own choice in selecting dresses for themselves.

- Men were found to be in the practice of specifying a price range for their purchase of garments although the willingness to pay more for the choicest is fast creeping in but still there is a limit to the price range only a very few particularly in the higher strata were found to be ready to pay exorbitant price for their choice. It so clearly evident that designers were looked upon by only a few males of Navi Mumbai .

- It was quite surprising to note that only a few man resorted to bargaining.

- Advertising perceptibly was found to be the most ought to after option for getting information about the new brand I flowing in the scene, followed by information by close contacts and accomplices.

- Advertising according to males as an assurance and strengthen loyalty towards brands.

- It was not surprising to note that male mostly preferred to see and pay attention to the advertising of the brands of garments they prefer to was seen as an attempt to find out what latest brand has to offer in design , style and fashion also to now whether there I any sort of sale promotion schemes associated to the brand in the form price slashing or contest, so that to avail them .men were found to be suggesting there close e friend, relatives and near ones about the brand they are using. So it was evident that if the user of a brand is satisfied there can be the advantage of word of mouth.

- Men are found in practice to pay attention to the brand suggested by their friends and close ones but the final choice was found to be an exclusive decision based on self assessment. 
- Growing brand patronage was found to be the prime reason for the growing popularity of exclusive showrooms even in micro metros like Navi Mumbai . It is therfore, such showrooms are fast inflowing in the scene.

- It I also a common practice that males preferring readymade offerings opted for readymade outfits in the entire garment assortments, shirts, trousers, shirts, suits, pullovers.

- Switches were find in abundance in this sections of consumers only a very few of the males prefer to stick to the brand they had used in the past. In other words prefer to be Brand Loyal. This was more in prominence in the higher income strata and the highly educated ones.

- Sales Promotion schemes coupled with rigorous advertising were found to be the primary reasons for switching followed by slashing of prices. Switching was found to be a general observable fact with the male to conclude worth it can be said that marketing today completely altered the nature and dynamics of business .marketing of products a taken primacy over the process of production itself these can be attributed to the fact that the new age consumer equipped with the effectual tool of advertising seeks more conception of the product, its features and its uses. And when this advertising is presented in an inspired and efficient manners it creates an perpetual notion on the consumers mind about brands and may even amend his acuity of what he needs brands are ever lasting in seeking challenge and searching for more and more consumers to be drawn into there field of influence and advertising in dubitable plays a momentous role in their pursuits

\section{References}

[1] Tom Peters, Circle of innovation Publisher Tata Mc GrawHill 1997

[2] Chunnawala SSA, Compendium of Brand Management, Himalaya Publishing House Mumbai,(2004).

[3] Danel T Seymure, Marketing research, publisher S Chand and Company.New Delhi (1995).

[4] James F Engel,David T Kollat and Roger D. Blackwell-Consumer Behavior. New York 1973)

[5] Suja Nair Consumer Behavior Text and Cases Himalaya Publishing house 2000

[6] R.Batra ,David A Aacker and John G.Myers Advertising Management,Tata Mc Graw Hill, New Delhi,1999.

[7] Ramaswamy \& Namkumari ,Marketing Management, Publisher Mac Millan 2004

[8] George E Belch \& Michael Belch,Advertising \& Promotion ,Publisher :Tata McGrawhill ,New Delhi 2007.

[9] Farris and Albion ,the impact of Advertisng on the price of Consumer Products “

[10] Robert 1 Steiner ,'Does advertising lower consumer price ?’Journal of Marketing 37,no.4 Oct 1990.

[11] Jagdish N Sheth "the Role of Motivation Research in consumer Psychology", Publisher Macmillan .

[12] Schiffman and Kannuk, Conumer Behaviour ,Publisher : Pearson 4th edition , (1991) 